\title{
Yield and Properties of Ethanol Biofuel Produced from Different Whole Cassava Flours
}

\author{
F. T. Ademiluyi, ${ }^{1}$ and H. D. Mepba ${ }^{2}$ \\ ${ }^{1}$ Department of Chemical/Petrochemical Engineering, Rivers State University of Science and Technology, 234 Port Harcourt, Nigeria \\ ${ }^{2}$ Department of Food Science and Technology, Rivers State University of Science and Technology, 234 Port Harcourt, Nigeria \\ Correspondence should be addressed to F. T. Ademiluyi; ademuluyi@yahoo.com
}

Received 3 October 2012; Accepted 22 October 2012

Academic Editors: G. Garrote and G. Ladics

Copyright ( 2013 F. T. Ademiluyi and H. D. Mepba. This is an open access article distributed under the Creative Commons Attribution License, which permits unrestricted use, distribution, and reproduction in any medium, provided the original work is properly cited.

\begin{abstract}
The yield and properties of ethanol biofuel produced from five different whole cassava flours were investigated. Ethanol was produced from five different whole cassava flours. The effect of quantity of yeast on ethanol yield, effect of whole cassava flour to acid and mineralized media ratio on the yield of ethanol produced, and the physical properties of ethanol produced from different cassava were investigated. Physical properties such as distillation range, density, viscosity, and flash point of ethanol produced differ slightly for different cultivars, while the yield of ethanol and electrical conductivity of ethanol from the different cassava cultivars varies significantly. The variation in mineral composition of the different whole cassava flours could also lead to variation in the electrical conductivity of ethanol produced from the different cassava cultivars. The differences in ethanol yield are attributed to differences in starch content, protein content, and dry matter of cassava cultivars. High yield of ethanol from whole cassava flour is best produced from cultivars with high starch content, low protein content, and low fiber.
\end{abstract}

\section{Introduction}

Ethanol is used extensively as a solvent in the manufacture of varnishes and perfumes; as a preservative for biological specimens; in the preparation of essences and flavorings; in many medicines and drugs; as a disinfectant and in tinctures (e.g., tincture of iodine); as a fuel and gasoline additive (Columbia Encyclopedia). Ethanol has been produced from different sources in the past. The generally accepted sources of raw material for alcohol production from starch are cereal grains such as corn, wheat, rye, barley, milo (sorghum grains), rice, potatoes, apple wine, and others $[1,2]$.

The use of nonfood sources such as microalgae to produce ethanol gave low yield of ethanol when compared with food crops like sugar cane and cassava. The highest ethanol production using spirogyra algae fermented with $Z$. mobilis was $9.70 \%$ ethanol ( $\mathrm{v} / \mathrm{v})$ with addition of $\alpha$-amylase enzyme at 0.09 grams for 96 hours, while using spirogyra algae fermented with $S$. cerevisiae the highest ethanol production was $4.42 \%$ ethanol $(\mathrm{v} / \mathrm{v})$ with addition of $\alpha$-amylase [3]. Therefore, Cassava starch is still a promising renewable resource in centuries to come as global reserves dwindles. In Nigeria, the national goal is to have a $10 \%$ blend that requires 1.27 billion litres of ethanol per year. Brazil, the world leading producer of this substitute, makes more than 120 million liters per year of ethanol from sugar cane and cassava. Promising ethanol returns, combined with higher crude oil prices throughout much of the year, have buoyed the demand for cassava in energy and alcohol production [4]. Also the carbohydrate content of cassava is higher than other root crop like potato, and so forth [5]. Ecofys 2007 reported that one tonne of fresh cassava roots yields 150 litres of ethanol and one tonne of dry cassava chips yields 333 litres of ethanol.

Several authors have carried out production of ethanol from cassava via acid and enzyme hydrolysis [6-8] using only one cassava cultivar. Onitilo et al. [9] reported that there were significant differences in the starch content, amylase, amylopectin, and total titrable acidity of different cassava varieties which are more than forty types (40), hence there is a need to investigate the yield and properties of ethanol biofuel produced from different cassava cultivars. Ethanol handing 
guide [10] also revealed that the electrical conductivity, gum, and water cement, as well as particulate content, are important physical properties that must be checked in fuel ethanol before operation, the acidity, as well as hydrocarbon content, and flash point are also important properties that describe the quality of ethanol fuel before usage.

Therefore, the objective of this work is to determine the yield and physical properties of biofuel (ethanol) produced from different whole cassava flours.

\section{Materials and Methods}

2.1. Materials and Equipments Used. Cassava cultivars: TMS 91/02324, TMS 92B/00061, TMS 92B/00068, TMS 98/0505, and TMS 98/0581, obtained from the International Institute of Tropical Agriculture (IITA) Onne., Rivers state Nigeria, refractometer, autoclave machine, conical flasks, spatula, industrial oven, pycnometer, thermostat, test tubes, thermometer, flash point apparatus, distillation apparatus, $\mathrm{pH}$ paper and meter, dry active yeast, yeast extract, potassium diphosphate, calcium chloride, magnesium sulphate, iron II sulphate (nutrients), sodium hydroxide for $\mathrm{pH}$ correction, sulphuric acid for hydrolysis, 95\% pure ethanol (used to prepare standard curve for ethanol), deionized water, pipette, buffer solution, and U-tubes capillary viscometer.

2.2. Experimental Procedure. $10 \mathrm{~kg}$ of each of the five cassava cultivars mentioned above were obtained from the International Institute of Tropical Agriculture (IITA), Onne. The roots were hand-peeled, washed separately, grated, and were pressed with a screw presser, the pressed roots were spread in separate trays in an open sun to remove initial moisture and dried in air oven to remove final moisture and, then, finally blended into fine particles as whole flour to increase the surface area.

2.2.1. Preparation and Sterilization of Growth Media. A semisynthetic broth media was prepared using the following: potassium diphosphate, ammonium sulphate, calcium chloride magnesium sulphate, iron II sulphate, and yeast extract. All were dissolved in one liter of distilled water in a conical flask. The solution was placed into an autoclave at a temperature of $121^{\circ} \mathrm{C}$ for 15 minutes and at a pressure of 15 psia to destroy any impurity that might inhibit a microorganism in the system and allowed to cool to $40^{\circ} \mathrm{C}$ before it was brought out of autoclave.

2.2.2. Acid Hydrolysis of Starch. $10 \mathrm{~g}$ of each of the whole cassava flour prepared from five different cassava cultivars (TMS 91/02324, TMS 92B/00061, TMS 92B/00068, TMS 98/0505, and TMS 98/0581) were added into $150 \mathrm{~mL}$ of 0.2 molar solution of diluted sulphuric acid in five conical flasks. The samples were allowed to stand for 90 mins, heated to $70^{\circ} \mathrm{C}$, and were stirred continuously to allow uniform temperature by attaching a temperature controller to the thermocouple. The hydrolysate was allowed to cool to $30^{\circ} \mathrm{C}$ and neutralized to $\mathrm{pH}$ of 6-7 with a known amount 0.5 molar solution of sodium hydroxide.
TABLE 1: Showing physical properties of commercial $98 \%$ ethanol.

\begin{tabular}{lc}
\hline Density and phase & $0.789 \mathrm{~g} / \mathrm{cm}^{3}$, liquid \\
Solubility in water & Fully miscible \\
Melting point & $-114.3^{\circ} \mathrm{C}(158.8 \mathrm{~K})$ \\
Boiling point & $78.4^{\circ} \mathrm{C}(351.6 \mathrm{~K})$ \\
Acidity $\left(\mathrm{p} K_{\mathrm{a}}\right)$ & $15.9\left(\mathrm{H}^{+}\right.$from OH group $)$ \\
Viscosity & $1.200 \mathrm{mPa} \cdot \mathrm{s}(\mathrm{cP})$ at $20.0^{\circ} \mathrm{C}$ \\
\hline
\end{tabular}

Source: Ethanol [11].

2.2.3. Inoculation of Sample. In order to determine the optimum amount of mineralized media and yeast required to produce optimum amount of ethanol, varying amount of mineralized media $(2.5 \mathrm{~mL}, 5 \mathrm{~mL}$, and $7.5 \mathrm{~mL})$ were added to on the hydrolysate of each of the five samples. The amount of active yeast required for fermentation was also varied. The mixture was turned into air tight containers (15 Nos, anaerobic system) after hydrolysis to enable fermentation. The effect of amount of cassava flour/acid ratio required to produce optimum yield of ethanol was also carried out by varying the cassava flour/volume of acid ratio. The yield of ethanol for the different whole cassava flours was monitored with fermentation period in hours for 6 days.

2.2.4. Distillation Process. The fermented mixture was heated using a thermostatic heater and distilled via simple doublebinary distillation to obtain ethanol biofuel from the different cassava flours.

2.3. Determination of the Properties of Ethanol. Appearance: The distillate was observed visually, using visual test method.

2.3.1. Ethanol Yield. Ethanol concentration was monitored using a refractometer via the refractive index method. The refractive index was determined with a refractometer (Bellingham and Stanley, England 1366A-3R). A calibration curve was obtained initially by diluting pure $98 \%$ ethanol in water to obtain different concentrations of ethanol and their corresponding refractive indexes obtained from the refractometer readings.

2.3.2. Flash Point. This test was carried out using Pensky Martens flash point apparatus. The cup in the apparatus was dried. $50 \mathrm{ml}$ of each sample (ethanol produced) was transferred into the flash point cup. The cup was fixed into the position in the apparatus assembled with thermometer, and the apparatus was switched on; the heat was controlled by a steady stirrer to maintain a uniform temperature while passing a small flame across the material every five seconds. The temperature at which the vapour first flashes with a blue flame was recorded as the flash point of the sample, after each test the cup was washed and dried before subsequent test. This was carried out twice for all the samples.

2.3.3. $p H$ Test. $\mathrm{pH}$ meter was first inserted in a buffer solution to standardize the apparatus then placed into the sample (ethanol) and the readings were obtained. 
TABLE 2: Effect of variation of ratio of cassava flour/volume of mineralized media and acid on ethanol yield for TMS 92B/00068.

\begin{tabular}{|c|c|c|c|c|}
\hline \multirow{2}{*}{ Experimental sets } & \multirow{2}{*}{$\begin{array}{l}\text { Ratio of cassava flour/volume } \\
\text { of media }(\mathrm{g} / \mathrm{mL})\end{array}$} & \multirow{2}{*}{$\begin{array}{l}\text { Ratio of cassava flour/volume } \\
\text { of acid }(\mathrm{g} / \mathrm{mL})\end{array}$} & \multicolumn{2}{|c|}{ Ethanol yield \% } \\
\hline & & & $24 \mathrm{hrs}$ & $48 \mathrm{hrs}$ \\
\hline \multirow{3}{*}{$\mathrm{a}$} & 4.0 & 0.1 & 15 & 18 \\
\hline & 10.0 & 0.25 & 22 & 26 \\
\hline & 20.0 & 0.30 & 42 & 46 \\
\hline \multirow{4}{*}{$\mathrm{b}$} & 2.0 & 0.0666 & 14 & 15 \\
\hline & 5.0 & 0.167 & 22 & 24 \\
\hline & 10.0 & 0.333 & 52 & 52 \\
\hline & 15.0 & 0.5 & 28 & 30 \\
\hline \multirow{4}{*}{ c } & 2.0 & 1.33 & 12 & 9 \\
\hline & 5.0 & 3.33 & 18 & 17 \\
\hline & 10.0 & 6.67 & 32 & 38 \\
\hline & 15.0 & 10.00 & 30 & 32 \\
\hline
\end{tabular}

TABLE 3: Yield, volume, and density of ethanol produced from different cassava cultivars.

\begin{tabular}{lccccc}
\hline Name of cassava used & $\begin{array}{c}\text { Density of first } \\
\text { distillate }(\mathrm{g} / \mathrm{mL})\end{array}$ & $\begin{array}{c}\text { Density of second } \\
\text { distillate }(\mathrm{g} / \mathrm{mL})\end{array}$ & $\begin{array}{c}\text { \% Ethanol } \\
\text { (weight in water) }\end{array}$ & $\begin{array}{c}\text { Volume of ethanol (mL)/g of cassava } \\
\text { flour produced after distillation }\end{array}$ & $\begin{array}{c}\text { Appearance } \\
\text { TMS 92B/00068 }\end{array}$ \\
fMS 92B/00061 & 0.9432 & 0.8206 & 88.7 & 0.60 & Colorless \\
TMS 91/02324 & 0.9409 & 0.8292 & 85.4 & 0.50 & Colorless \\
TMS 98/0505 & 0.9572 & 0.8825 & 86.9 & 0.55 & Colorless \\
TMS 98/0581 & 0.9463 & 0.8284 & 85.7 & 0.42 & Colorless \\
\hline
\end{tabular}

2.3.4. Density and Specific Gravity Test. Empty pycnometer was weighed. The pycnometer was filled with sample (ethanol), the excess was wiped off, the weight was recorded, and the density calculated using the formula:

$$
\text { Density }(\mathrm{g} / \mathrm{mL})=\frac{\text { mass }}{\text { Volume }} \text {. }
$$

Secondly, distilled water was filled into the pycnometer, weighed and recorded. The specific gravity was calculated using the formula:

$$
\text { Specific gravity }(\mathrm{Spg})=\frac{\text { density of Ethanol }}{\text { Density of Water }} \text {. }
$$

2.3.5. Viscosity Test. $50 \mathrm{ml}$ of ethanol was turned into A-arm of U-tube capillary viscometer through the orifices to the marked point. A sucker was used to lift the sample to the B-arm of the capillary to the marked point. A stop watch was used to regulate the time it took the ethanol to return (flow) to the mark under the B-arm, and the time noted. Viscosity calibration curve was then used to convert viscosity in seconds to centistokes.

2.3.6. Distillation Range Test. A known volume of the ethanol was turned into ASTM distillation flask, fixed at its position, A thermometer inserted at the top and the heater was switched on. A receiver (cylinder) was kept at the distillate recovery point. The temperature reading was taken at the first drop of the distillate. As the temperature increased, the distillate increased in volume until there was a decrease in distillate and at the last drop the final temperature and volume were noted.

2.3.7. Electrical Conductivity Test. Hi 8033 digital electrical conductivity meter (Hanna Instrument, Portugal) was used. A known quantity of ethanol produced from the different cultivars was poured into a beaker. The electrode was immersed to the censor market point. The meter was turned on to the required calibrated units and the reading was taken for all the samples when a stable reading was established.

\section{Results and Discussion}

3.1. Effect of Quantity of Yeast on Ethanol Yield from Different Whole Cassava Flours. Figures 1, 2, and 3 show the effect of the amount of yeast used on the yield of ethanol produced from different cassava cultivars. Generally, the yield of ethanol produced increased with fermentation time and later decreased. It shows that increasing the amount of yeast ( $3 \mathrm{~g}-9 \mathrm{~g}$ ) along with the amount of mineralized media used also affects the yield of ethanol produced from different cassava cultivars. Comparing the fermentation times on Figures 1, 2, and 3; it was observed that increasing the quantity of yeast reduced the fermentation time, when $3 \mathrm{~g}$ of yeast was used the fermentation time was $120 \mathrm{hrs}$, while $6 \mathrm{~g}$ and $9 \mathrm{~g}$ of yeast required $72 \mathrm{hrs}$ to produce over $25 \%$ ethanol. Although increasing the yeast to $9 \mathrm{~g}$ reduced the fermentation time and increased quantity of ethanol produced, it was 
TABLE 4: Distillation range and flash point of ethanol from different cassava cultivars.

\begin{tabular}{lcccc}
\hline Type of cassava used & Initial volume of distillate $(\mathrm{mL})$ & Final volume of distillate $(\mathrm{mL})$ & Distillation range $\left({ }^{\circ} \mathrm{C}\right)$ & Flash point $\left({ }^{\circ} \mathrm{C}\right)$ \\
\hline TMS 92B/0068 & 82 & 72 & $78-99$ & $79-100$ \\
TMS 91/02324 & 82 & 69 & $78-100$ & 15 \\
TMS 92B/0061 & 82 & 70 & $79.5-100$ & 24 \\
TMS 98/0505 & 82 & 67 & $78-100$ & 19 \\
TMS 98/0581 & 82 & 69 & & 23 \\
\hline
\end{tabular}

TABLE 5: Electrical conductivity, viscosity, and $\mathrm{pH}$ of ethanol from different whole cassava flours.

\begin{tabular}{lccc}
\hline $\begin{array}{l}\text { Type of cassava } \\
\text { used }\end{array}$ & $\begin{array}{c}\text { Electrical } \\
\text { conductivity }(\mu \mathrm{s} / \mathrm{m})\end{array}$ & $\begin{array}{c}\text { Viscosity } \\
(\text { CST })\end{array}$ & $\mathrm{pH}$ \\
\hline TMS 92B/00068 & 329 & 1.99 & 6.11 \\
TMS 91/02324 & 330 & 2.1 & 6.55 \\
TMS 92B/0061 & 230 & 2.0 & 6.71 \\
TMS 98/0505 & 300 & 2.02 & 6.68 \\
TMS 98/0581 & 150 & 2.2 & 6.78 \\
\hline
\end{tabular}

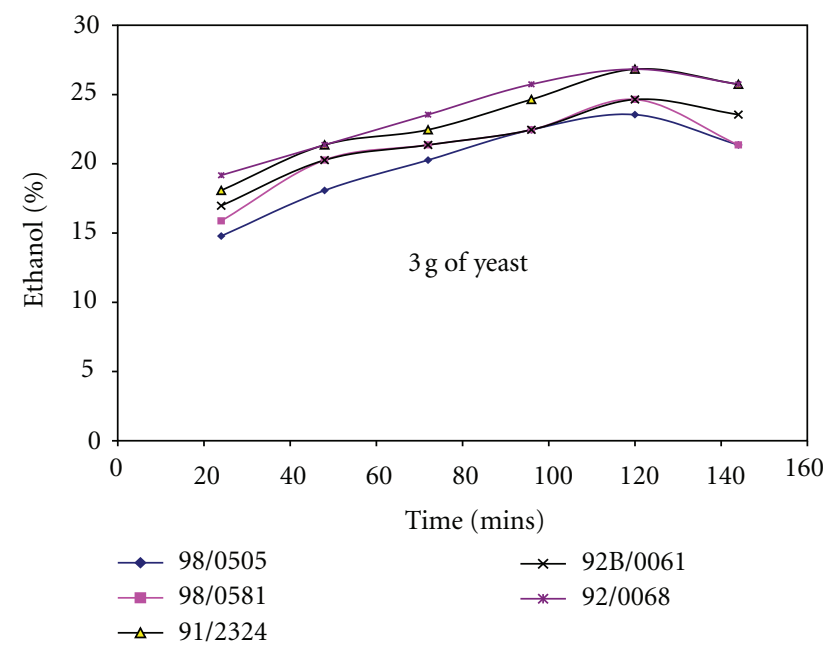

FIGURE 1: Ethanol yield for different cassava cultivars using $3 \mathrm{~g}$ of yeast.

observed the resultant solution produced after fermentation was too cloudy due to much yeast. Hence, $6 \mathrm{~g}$ of yeast to $5 \mathrm{ml}$ of mineralized media was preferred, this gave higher yield of ethanol at shorter fermentation time for all the cassava cultivars and was used as basis for production of ethanol from cassava in other studies carried out in this work.

Ethanol produced from whole cassava flours TMS 92/00068 and TMS 91/02324 shows consistent increase in ethanol yield irrespective of the quantity of yeast and mineralized media used as shown in Figures 1, 2, and 3. It was also observed that yield of ethanol produced from cassava flour TMS 98/0505 was the least as shown in Figures 1, 2, and 3 irrespective of the quantity of yeast and mineralized media used.

3.2. Effect of Whole Cassava Flour to Acid and Mineralized Media Ratio on the Yield of Ethanol Produced. It was observed

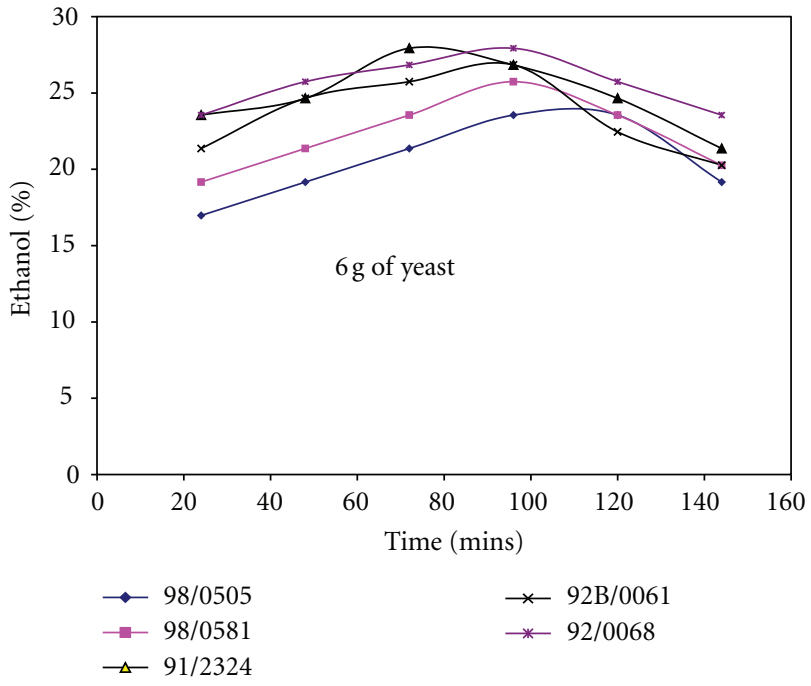

FIGURE 2: Ethanol yield for different cassava cultivars using $6 \mathrm{~g}$ of yeast.

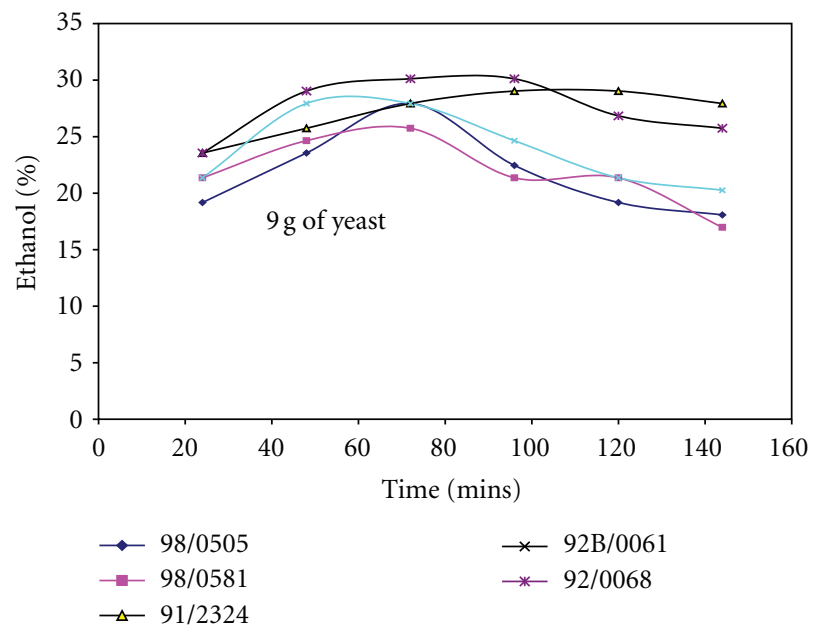

FIGURE 3: Ethanol yield for different cassava cultivars using $9 \mathrm{~g}$ of yeast.

from Figures 1, 2, and 3 that the yield of ethanol produced was between 15 and 30\% using whole cassava flour to acid ratio of $1: 15(\mathrm{w} / \mathrm{v})$ in the production of ethanol. Hence, quantity of whole cassava flour and acid used was optimized to obtain higher yield of ethanol. Table 2 shows the effect of cassava flour/volume of media and acid ratio on the yield of ethanol 
TABLE 6: Average starch, dry matter, protein content, cyanide, and yield per hectare of fresh cassava cultivars used.

\begin{tabular}{lccccc}
\hline Cassava cultivars & Starch content \% & Protein \% & Dry matter \% & Cyanide level \% & $\begin{array}{c}\text { Yield of fresh cassava root } \\
\text { tonnes/hectares }\end{array}$ \\
\hline TMS 92B/0068 & 67.15 & 1.72 & 28.235 & 4.91 & 26.07 \\
TMS 92B/0061 & 65.90 & 2.71 & 35.63 & 3.95 & 29.35 \\
TMS 91/02324 & 67.75 & 4.55 & 27.615 & 6.81 & 21.09 \\
TMS 98/0505 & 49.82 & 3.42 & 34.18 & 2.01 & 29.03 \\
TMS 98/0581 & 47.04 & 3.22 & 35.22 & 2.60 & 25.67 \\
\hline
\end{tabular}

Source: IITA Onne report [12].

produced for TMS 92B/00068. This analysis was carried out only for TMS 92B/00068 alone since this cultivar produced the highest yield of ethanol compared with other cultivars as shown in Figures 1, 2, and 3. Table 2 shows that variation in the amount of cassava flour to volume of acid ratio as well as amount of cassava flour to volume of mineralized media ratio used has significant effect on ethanol yield. Increasing flour/volume of acid ratio increased the ethanol yield to an optimum value of $52 \%$ within 48 -hour fermentation time and further increase in flour/acid and media ratio reduce the yield of ethanol produced. The optimum value of ethanol was produced using $0.333 \mathrm{~g} / \mathrm{mL}$ (cassava flour/volume of acid) and $10 \mathrm{~g} / \mathrm{mL}$ (ratio of cassava flour/volume of mineralized media) for TMS 92B/00068 fermented for $72 \mathrm{hrs}$.

\subsection{The Properties of Ethanol Produced from Different Cas-} sava. Table 3 shows the yield of ethanol produced from different whole cassava flours. The use of $0.333 \mathrm{~g} / \mathrm{mL}$ of cassava flour/acid ratio of the different cassava cultivar produced $88.7-82.5 \%$ ethanol as shown in Table 3 after $72 \mathrm{hrs}$ of fermentation and distillation. The volume of ethanol produced by different cassava cultivars varied significantly. TMS $92 \mathrm{~B} / 00068$ had the highest ethanol produced $(0.61 \mathrm{~mL} / \mathrm{g}$ of cassava flour) after distillation, while TMS 98/0505 produced the least amount of ethanol $(0.42 \mathrm{~mL} / \mathrm{g}$ of cassava flour $)$ as shown in Table 3. The density of ethanol produced from the different cassava cultivars was different after double distillation. Percentage ethanol by weight in water also differs significantly from the different cassava cultivars, with TMS $92 \mathrm{~B} / 00068$ yielding up to $88.7 \%$ ethanol by weight in water after second distillation. Further distillation using fractional azeotropic distillation or dehydrating will be required to obtain ethanol of about $95-98 \%$ weight in water as shown in Table 1 . All the ethanol produced was clear and colorless. The result in Table 3 shows that different cassava cultivars will not produce the same yield and density of ethanol.

Table 4 shows the distillation range of ethanol obtained from the different cassava cultivars. The distillation range of the ethanol produced from the different flours lies between $78-100^{\circ} \mathrm{C}$ with TMS $92 \mathrm{~B} / 00068$ having the least value. This was expected since TMS 92B/00068 has the highest ethanol weight in water. Commercial (98\%) ethanol has a boiling point of $78.4^{\circ} \mathrm{C}$ from Table 1 . The difference in the distillation range of the different cassava cultivars was due to the variation in the densities of the ethanol produced from the different cassava cultivars. The flash point of different ethanol produced from the cassava whole flours were also presented in Table 4 . The flash point value ranged between $15-24^{\circ} \mathrm{C}$ for ethanol weight in water of $88.65-82.49 \%$. Standard ethanol from corn of $98 \%$ ethanol in water had a flash point of $13^{\circ} \mathrm{C}$ from Table 1, which can be obtained for ethanol from cassava using fractional distillation. TMS 92B/00068 still had the least flash point of $15^{\circ} \mathrm{C}$ compared with other cassava cultivars and will invariably have the highest heat of combustion. The lower the flash point, the better and faster the ignition of fuel. The difference in the flash point of the different cassava cultivars is also due to the variation in the densities of the ethanol produced from the different cassava cultivars also TMS 92B/00068 has more ethanol by weight in water.

Table 5 shows the viscosity, electrical conductivity, and $\mathrm{pH}$ of ethanol from different whole cassava flours. The viscosity and $\mathrm{pH}$ varied slightly while the electrical conductivity of ethanol from the different cassava cultivars varied significantly. The electrical conductivity of fuel ethanol is an important parameter used when measuring fuel quality. A conductivity not more than $500 \mu \mathrm{s} / \mathrm{m}$ is recommended [10]. The values obtained for cassava ethanol for all the cultivars is still within the required range of $500 \mu \mathrm{s} / \mathrm{m}$. TMS 92B/00068 and TMS 91/02324 have the highest electrical conductivity from Table 5 while TMS 98/0581 has the least, this result was expected since TMS 92B/00068 has high flash point compared with other cultivars. The work carried out by Adeniji et al. [13] on the mineral composition of five improved varieties of cassava showed that the mineral composition (sodium, magnesium, potassium, copper, zinc, iron, and phosphorus) of the five varieties of cassava studied varies significantly. This variation in mineral composition of the different whole cassava flours could also leads to variation in the electrical conductivity of ethanol produced from the different cassava cultivars.

Table 6 shows the average starch, dry matter, protein content and yield per hectare of fresh cassava cultivars used. TMS 92B/00068 and TMS 91/02324 had the highest average starch content and lowest \% dry matter. From Tables 3 and 4, TMS 92B/00068 had the highest volume of ethanol produced after distillation and lowest flash point than other cultivars, while TMS 98/0505 and TMS 98/0581 had lower volume of ethanol produced after distillation. The high yield of ethanol produced using TMS 92B/00068 and TMS 91/02324 than other cultivars may be due to its high starch content. Cassava cultivar, TMS 91/02324, would be expected to produce more ethanol than TMS 92B/00068, because it had more starch content but from Table 6 the protein content of TMS 91/02324 is higher than the protein content of TMS 
92B/00068, which shows that the low protein content also favours the yield of ethanol produced by the different cassava cultivars. In addition to high starch content, TMS 92B/00068 and TMS 91/02324 had low dry matter from Table 6. Low dry matter is a reflection of low fiber content. Low fiber content of cassava cultivars TMS 92B/00068 and TMS 91/02324 enhances the yeast to break down the hydrolysed starch to ethanol easily. The high cyanide content of TMS 92B/00068 and TMS 91/02324 did not affect the ethanol yield, cyanide content must have reduced during washing, dewatering, and drying of the fresh cassava roots to flour.

\section{Conclusion}

The yield and properties of ethanol biofuel produced from different whole cassava flours was investigated. Yield and physical properties (distillation range, density viscosity, flash point, and electrical conductivity) of ethanol produced differ for different cassava cultivars. Optimum yield of ethanol was obtained using $0.333 \mathrm{~g} / \mathrm{mL}$ (cassava flour/volume of acid) and $10 \mathrm{~g} / \mathrm{mL}$ (ratio of cassava flour/volume of mineralized media) for TMS 92B/00068 fermented for $72 \mathrm{hrs}$. The differences in ethanol yield are attributed to differences in starch content, protein content, \% dry matter, and mineral composition of cassava cultivars. Hence to produce high yield of ethanol with good physical and electrical properties from whole cassava flour, cassava cultivars with high starch content, low protein content, and low dry matter should be used, while the cassava cultivars with moderate starch content $(<50 \%)$, high protein, and high fiber content can be used as food for human consumption and in food products.

\section{References}

[1] D. Wang, Y. Xu, J. Hu, and G. Zhao, "Fermentation kinetics of different sugars by apple wine yeast Saccharomyces cerevisiae," Journal of the Institute of Brewing, vol. 110, no. 4, pp. 340-346, 2004.

[2] B. C. Akin-Osanaiye, H. C. Nzelibe, and A. S. Agbaji, "Production of ethanol from Carica papaya (pawpaw) agro waste: effect of saccharification and different treatments on ethanol yield," African Journal of Biotechnology, vol. 4, no. 7, pp. 657-659, 2005.

[3] Sulfahri, S. Mushlihah, E. Sunarto, M. Yusuf Irvansyah, R. S. Utami, and S. Mangkoedihardjo, "Ethanol production from algae Spirogyra with fermentation by Zymomonas mobilis and Saccharomyces cerevisiae," Journal of Basic and Applied Scientific Research, vol. 1, no. 7, pp. 589-593, 2011.

[4] FAO Corporate Document Repository, "Food Outlook-Cassava Prices," 2009, http://www.fao.org/ag/magazine/0610sp1 .htm.

[5] FAO Corporate Document Repository, "Establishment of a cassava starch factory," 2012, http://www.fao.org/docrep/x5032e/ x5032E05.htm.

[6] P. Atthasampunna, P. Somchai, A. Eur-aree, and S. Artjariyasripong, "Production of fuel ethanol from cassava," World Journal of Microbiology and Biotechnology, vol. 3, no. 2, pp. 135-142, 1987.

[7] Z. Yu and H. Zhang, "Ethanol fermentation of acid-hydrolyzed cellulosic pyrolysate with Saccharomyces cerevisiae," Bioresource Technology, vol. 93, no. 2, pp. 199-204, 2004.
[8] S. A. Ado, G. B. Olukotun, J. B. Ameh, and A. Yabaya, "Bioconversion of cassava starch to ethanol in a simultaneous saccharification and fermentation process by co-cultures of Aspergillus niger and Saccharomyces cerevisiae," Journal of Pure and Applied Microbiology, vol. 4, no. 1, pp. 55-61, 2010.

[9] M. O. Onitilo, L. O. Sanni, I. Daniel, B. Maziya-Dixon, and A. Dixon, "Physicochemical and functional properties of native starches from cassava varieties in Southwest Nigeria," Journal of Food, Agriculture and Environment, vol. 5, no. 3-4, pp. 108-114, 2007.

[10] US Energy Department, Ethanol Handing Guidebook, 2008, http://www.afdc.energy.gov/pdfs/41853.pdf.

[11] Ethanol, Wikipedia Encyclopedia, 2012, http://en.wikipedia. org/wiki/Ethanol.

[12] IITA Onne Report, Improved Variety Hand Book, 2010, http://www.iita.org/c/document_library/.

[13] T. A. Adeniji, L. O. Sanni, I. S. Barimalaa, and A. D. Hart, "Mineral composition of five improved varieties of cassava," Nigerian Food Journal, vol. 25, no. 2, pp. 39-44, 2007. 

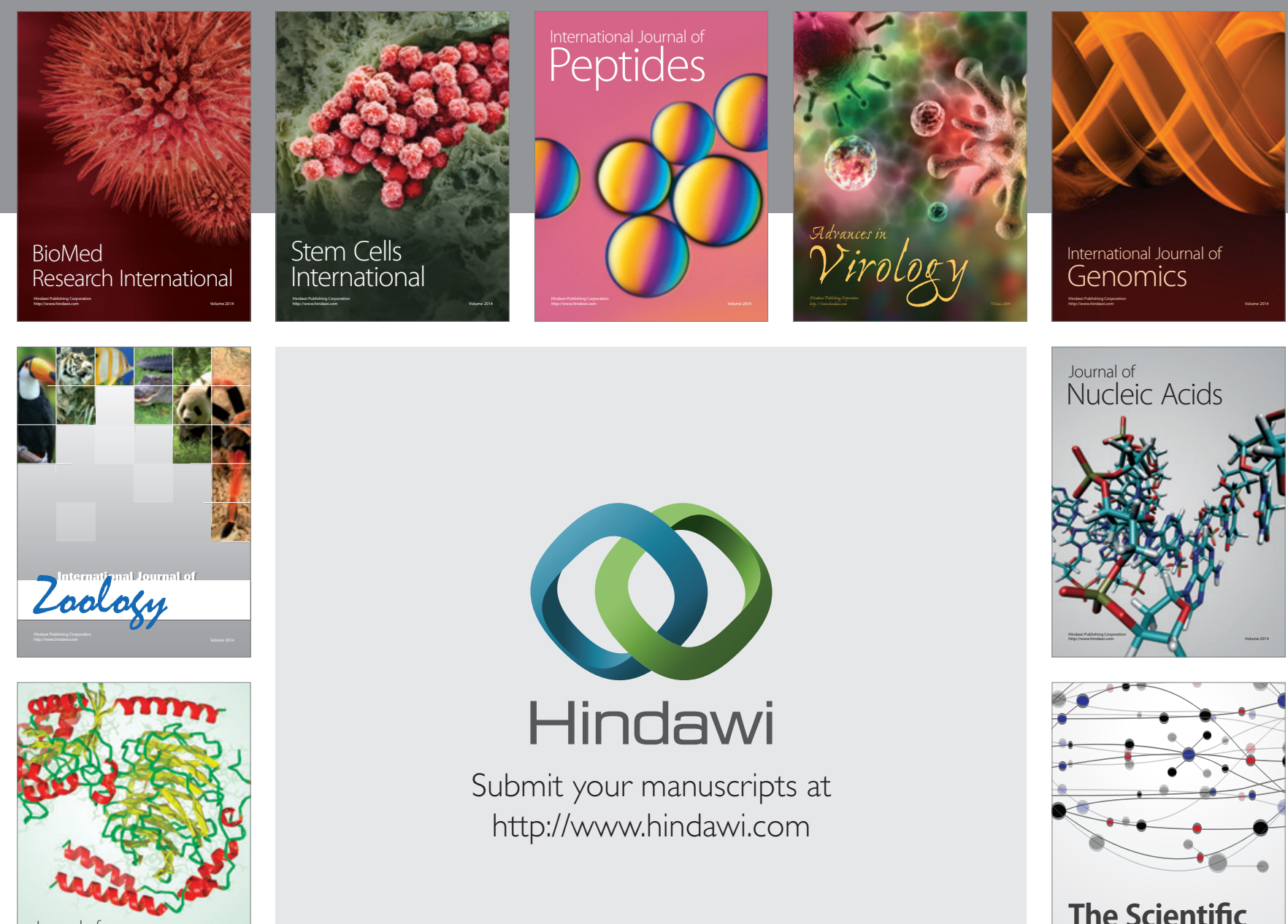

Submit your manuscripts at

http://www.hindawi.com

Journal of
Signal Transduction
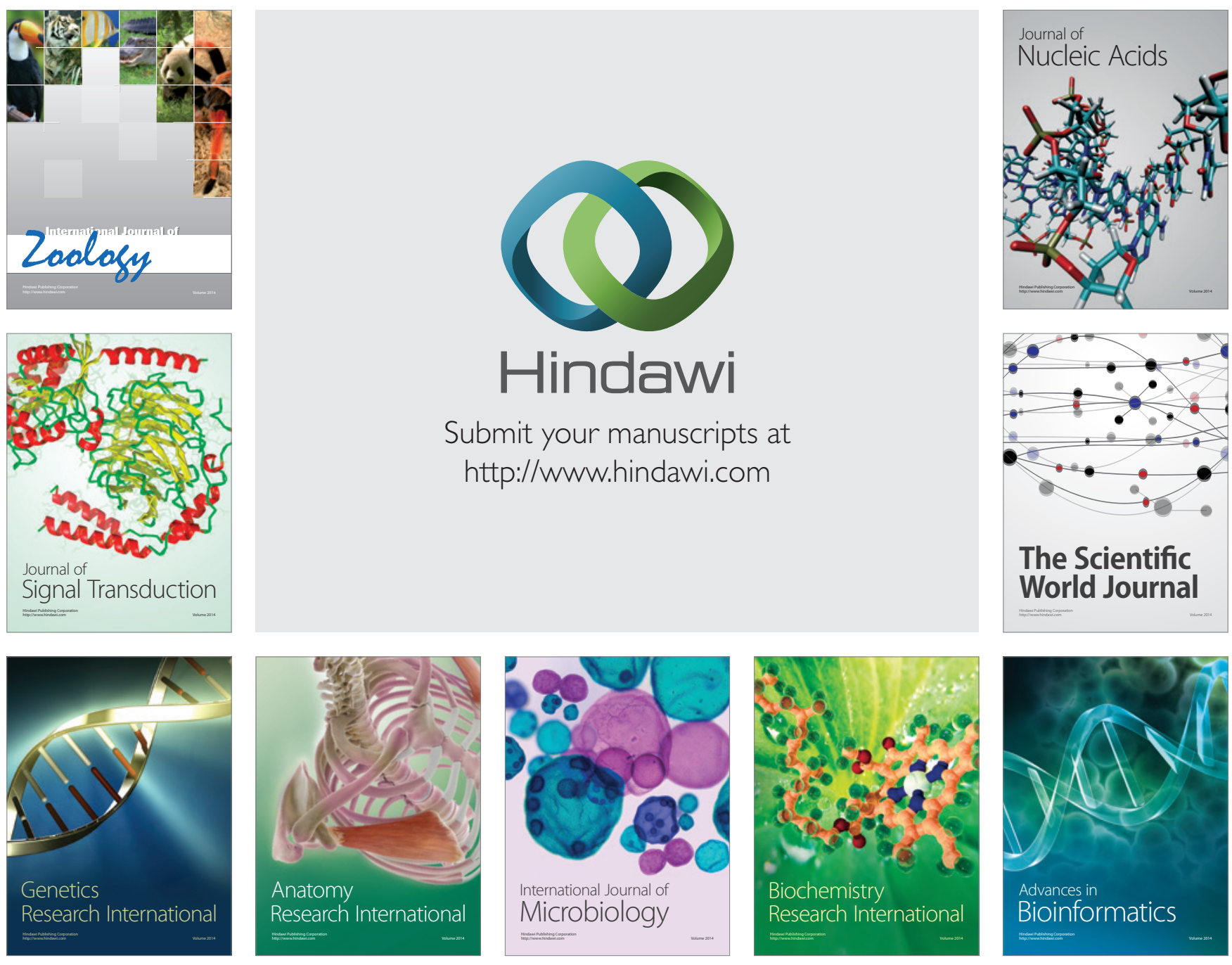

The Scientific World Journal
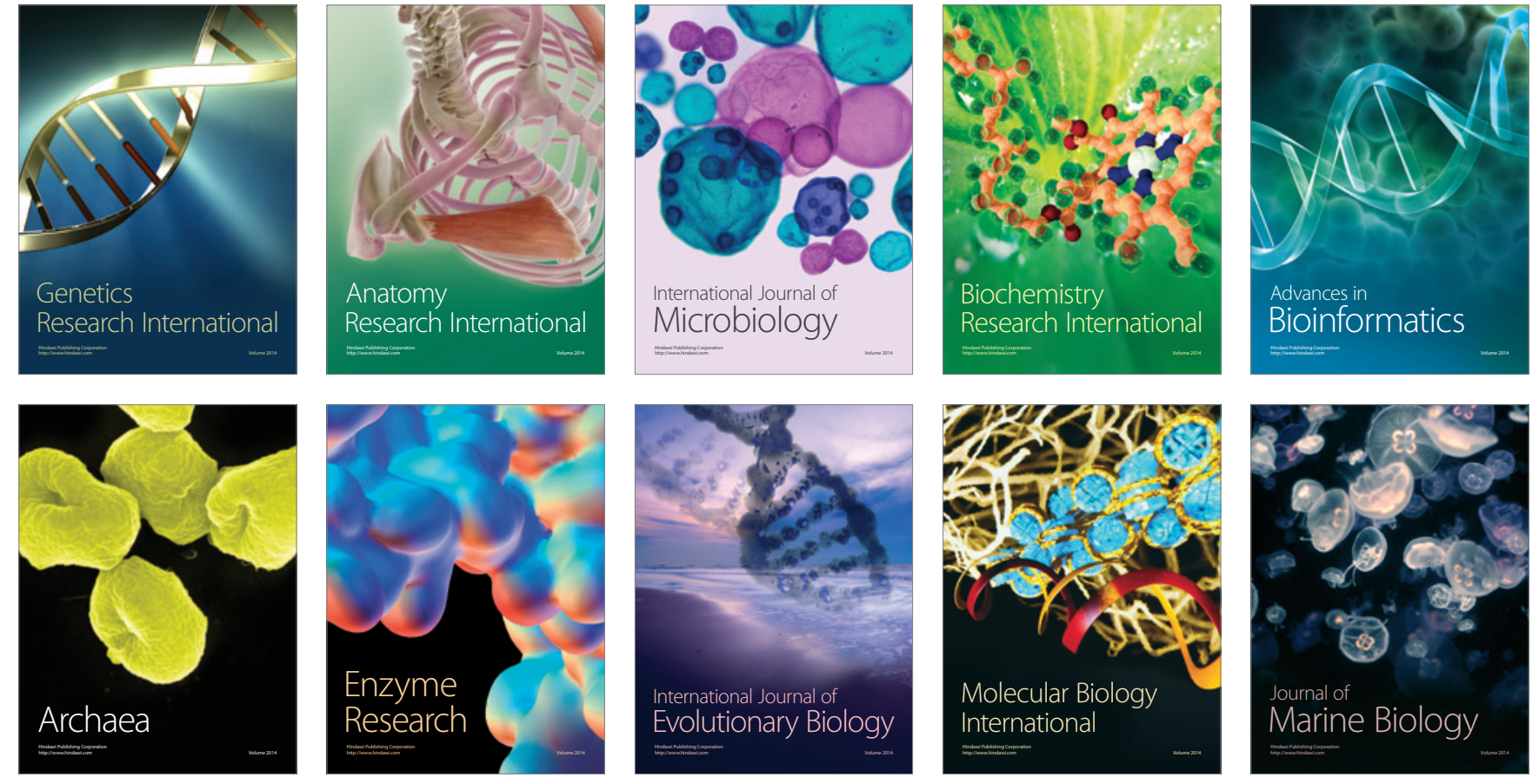